\title{
ESTATE PLANNING
}

\author{
F. E. LaBRIE*
}

\section{THE LAWYER'S PROFESSIONAL ROLE IN ESTATE PLANNING}

Estate planning is not a new area of activity for the legal profession. In point of fact it its one of the oldest, and dates back to feudal England when much planning was directed to the avoidance of feudal dues and incidents. The efforts of lawyers in later times to maintain land in the ownership of families has provided the background for development of much of our land law of today. Similar care for the spendthrift and incompetent relatives of wealthy men have contributed to our law of property and of trusts. The role of the solicitor of nineteenth-century England, acting as confidant, business adviser and close associate of the family head, is too well known to require description or comment.

Yet today there has been a revival of interest in estate planning which, generally, can be described as planning directed toward the proper division and distribution of wealth. The problem of division of wealth remains as always, a problem of how to divide ownership of the wealth both vertically and horizontally so as to achieve client objectives. The area of estate planning has received renewed interest and impetus in modern times due to the phenomenal increase in income tax, death duties, and gift taxation as methods of raising revenue for financing the expanding role of modern government.

The present progressive system of taxation represents a tremendous outlay even to persons of moderate wealth. This fact accounts for an expanded area of persons interested in planning, and a greatly increased cost of failing to plan. The problem is essentially one of superimposing old ideals on new law. The ideal of thrift and of saving and of monetary incentive as the purpose and basis for productive activity has had to be superimposed on a law of redistribution of wealth on a new basis of social welfare. In large measure the function of estate planning can be looked upon as an exercise in attempting to preserve the rewards of industry for a generation of people who still expect them.

\section{PLANNING AS A METHOD OF TAX MINIMIZATION}

Too much emphasis has been placed on tax planning and on the avoidance of taxes as comprising the basis in estate planning, and there are obvious dangers in over-planning for the avoidance of taxes. The main objective of estate planning is, as it has always been, to carry out the taxpayer's wishes and objectives. René Wormser, one of the outstanding United States authorities in the field of estate planning, has stated this position clearly and no one seriously questions it. However, as he also points out, the solicitor's duty does not end with simply drafting a will and deed in legally unassailable form to carry out to the letter the instructions the client may have given him. The complexity of the subject and the high cost of taxation does place on the lawyer a duty at least to advise

- Francis Eugene LaBrie, B.A.. LL.B., LL.M., D.Jur., of the Alberta and Ontario Bars. Speclal Lecturer in the Faculty of Law, Unlverslty of Western Ontarlo. 
the client of alternative ways of meeting his objectives. Moreover, this duty extends to questioning the client on the reasons lying behind his objectives in disposing of his estate to assist him in clarifying his own mind and arriving at what he truly desires. Largely, this process follows the accepted practice of explaining to clients the types and manners of dispositions and the methods of dividing up the ownership of property.

Wormser ${ }^{1}$ has laid down what he described as basic objectives in estate planning which, in his order of importance, are as follows:

1. Liquidity, or leaving the estate with sufficient funds to meet taxation and other costs arising in the event of death.

2. Flexibility, leaving the taxpayer able to modify and amend the plan of distribution in order to accommodate to changing conditions. The rapid change of taxation legislation makes this principle all the more important to observe.

3. Tax saving, which simply means the choice of alternative ways of meeting the taxpayer's objectives of liquidity and flexibility with the smallest possible outlay in taxes.

4. Earning capacity is more important than property, both in regard to the client and his beneficiaries. The importance of this principle is ignored not only by taxpayers, but also by governments. It simply means that opportunity is more valuable in life than security and that the availability of opportunity is one of the best guarantees for survival, both individually and collectively.

Modern tax law, translated into practical terms, means that wealth must be liquidated and redistributed periodically. In the area of income tax the distribution is annual and the liquidation of wealth for that reason does not often present a great problem, though sometimes income in form other than cash or income irregularly received will give rise to financial embarrassment and undue tax burden. The greatest challenge arises in the area of death duties where the imposition is but once in a lifetime, is often unexpected, and takes a heavy toll of wealth that is frequently not in liquid form. From one point of view the aim of estate planning is to preserve the taxpayer's (and society's) wealth against the destruction that might come about through heavy death duties. Apart from the quantity of money actually raised, the loss to the taxpayer and to the community of a carefully built and productive enterprise that has to be liquidated to provide taxes can be considerable.

\section{RIGHT OCCASIONS FOR ESTATE PLANNING}

Ralph Loffmark has recently written a looseleaf manual called Tax and Estate Planning. ${ }^{2}$ The choice of title is commendable, for it indicates the simple truth that taxation is part of the ordinary commercial law of this day and age, though it is preferable to regard taxation not as a field of law but as an element ever present in the law of property, of wills and trusts, and of business organization, that must be taken into account at all times. Estate planning has sometimes been regarded as a form of undertaking that arises late in a taxpayer's life, as a sort of special investigation into his affairs to minimize impending estate taxes, but from the standpoint of the solicitor, estate planning remains essentially 
an area of activity that pervades all of his work. The plan of a man's estate is a matter that should be considered in connection with every form of legal transaction, though of course the advice given need not be the same at all times. The advice to be given to a client 35 years of age about to purchase land or enter into a partnership may very well differ from that applicable to another 65 years of age.

\section{THE PROPER USE OF OUTSIDE ASSISTANCE}

As the problems of estate planning increase in complexity, in fluctuation, and in number, the need and opportunity may arise for specialization to a degree not possible for the average solicitor, so that other expert services will be necessary. Estate planning has sometimes been described as the work of a team, which may comprise a life insurance underwriter, an accountant, an investment counsel, a valuator, a trust officer, and, finally, a lawyer. Though each of these other vocations is vested with special knowledge or competence to assist in estate planning, none of them is in a position to carry out estate planning properly singlehanded. Life underwriters are in the field because they have something to sell. Their form of estate planning is attractive because there is no direct charge for it; but there is little to merit their entry into the field of estate planning beyond advising on the types of insurance and their possible uses. The same observation is applicable to other groups mentioned. The accountant is favourably situated in that his work takes him closely into the client's business affairs from which position he can assess the need for a plan, can impress his client with the dangers of neglecting to plan, and can stimulate his interest in doing something about it. Advice from any source in regard to estate planning and particularly the taxation aspect of it, cannot be properly undertaken except by someone trained in knowing the full legal significance of every step that must be taken in implementing the advice.

The lawyer who does not wish to develop the skills and abilities of these other vocations nevertheless has an important service that he can and should render. He can select or recommend these experts, judge their competence, supervise and revise their work, and weigh the practical wisdom of suggestions they may make. Finally, he can insist on his position of independence in giving his client advice in relation to any aspect of it. The life underwriter's opinion is unquestionably influenced by his desire to sell insurance. The accountant may be well versed in the arithmetic of tax saving and, while independent in his advice, may nevertheless be providing dangerous advice from the standpoint of its legal effect. Investment counsel are undoubtedly interested in investment and we even hear of investment counsel being regularly paid commissions for the shares disposed of as a result of their advice. Valuators may boast of the general acceptance of their valuations by tax officers, which position is easy of attainment by simple process of overvaluation. The responsibility for estate planning rests ultimately on the lawyer whose position as independent adviser, charging on a straight fee basis for time spent and advice given, renders him best suited to this important function that has traditionally belonged to his profession.

Lawyers should therefore not hesitate to raise the question of the client's estate whenever it seems appropriate to do so, notwithstanding 
that the lawyer has not been specially consulted in that connection. There could not be said to be any violation of professional ethics in a lawyer showing an honest and alert curiosity in reminding his client of the need for planning his estate and drawing the subject to his attention. In addition, where planning is undertaken, the lawyer should assert his position as leader, dominant factor and controlling personage in any team work that is to be carried out, at the same time assuming his proper measure of responsibility for what is eventually done. In drafting plans for complicated estates a large amount of study and effort is obviously required and considerable time must be given to studying the client's tax position. Naturally, with experience, patterns emerge and familiar techniques develop.

Finally, it is not sound planning to base any proposed plan on the expected outcome of litigation. Planning must be carried out within the accepted meaning of tax legislation. This does not necessarily mean that estates should be planned in an effort to avoid all opportunity for litigation: where a course of action is undertaken on the assumption that tax is to be paid, and yet may be carried out in such a way as to raise doubt whether tax must be paid, there is no harm in raising that doubt. When the issue arises for determination the taxpayer or his beneficiaries may decide that they wish to litigate, notwithstanding that the plan presupposed payment of tax. Moreover, in the interim between execution and assessment, someone else may have litigated the point to successful conclusion, and the taxpayer is then in a position to take advantage of this legal development. Also, it is not sound planning to rely upon a legislative loophole that was unintended and likely to be amended, unless such reliance is not beyond recall, or unless amendment will be too late to affect the arrangement made. Your client may not be the first to die after having planned in reliance upon the loophole. Retroactive tax amendment is uncommon, though there have been instances of it in the last few years.

\section{ARRANGING THE ESTATE}

Estate planning does not require a profound knowledge of taxation, but it does require a thorough knowledge of the main principles. Planning an estate can be roughly divided into two different areas. The first of these deals with property passing and presupposes that the taxpayer has chosen to die with an estate of predetermined size, relating merely to the manner in which that estate is to be held in order to render it as little taxable as possible. It is obvious that for reasons of security and, perhaps, through life-long habit, the taxpayer may be reluctant to part with any of his property before he dies. In this area of what is clearly property passing on death, certain precautions can be taken to prevent undue embarrassment and cost to the estate. The second area, discussed below, relates to the optimum size of the estate.

\section{Localization of Assets}

The principal question in the first area is the localization of estate assets. In Canada there are presently three provinces that impose succession duties: British Columbia, Ontario, and Quebec. All of them impose taxation on property situated within their borders, and although there is Dominion tax credit to the extent of one-half the federal tax, that credit does not completely remove the increased tax due to multiple 
taxation. The tax treaties should be consulted in connection with property in foreign countries. For example, property to a value of $\$ 15,000$ can be owned in the United States by Canadian domiciled decendents free of United States death taxes. But this exemption does not bar taxation by the individual States of the United States. Also, it should be noted that considerable increase in the cost of administering the will may be incurred through multiple situs.

Obvious care should be taken therefore to insure that, wherever possible, assets are not allowed to have a situs in British Columbia, Ontario, or Quebec. With movable property, a problem seldom arises, with the exception of intangibles such as shares and bonds. Where there are multiple share registries, shares can frequently be placed outside of those three provinces by simply maintaining the share certificates on deposit in any of the other provinces where a share register is located. Where there is no registry other than in those three provinces there is no way of establishing elsewhere the situs of the shares as such, though their situs may be altered through a trust or holding corporation, as mentioned below. Where the shareholding is not large enough to warrant expensive treatment, consideration should be given to disposing of these shares and substituting other investments for them, if satisfactory substitutes can be found.

Even where share situs can be legally excluded from a taxing province a problem may arise after death of persuading the share transfer agency (usually a trust company) from refusing, out of an excess of caution, to register transfers without succession duty clearances from every conceivable jurisdiction with which the agency wishes to maintain good relations. This problem can be avoided by having the client endorse share certificate transfer forms in blank (street certificates) so that the transferee himself can seek registration.

Where Ontario, Quebec or British Columbia property is held in the form of real estate or other wealth that is either immovable or of special value to the taxpayer it can be effectively excluded from taxation in those jurisdictions by altering its form. A holding corporation with shares situated in Alberta can hold property in any part of the world, which property will not devolve on the taxpayer's death, because his wealth is now represented by shares in the holding company. ${ }^{3}$ A trust may also be employed in this connection and involves less expenditure. Every caution must be exercised in this use of the trust, because courts have on occasion taken the view that the beneficiary owns the trust property and cannot properly be described as owning a mere right in personam against the trustee. 4 The line of demarcation in these two situations has never been clearly drawn, but the distinction would appear to rest on the terms of the trust. There are three variables: the certainty of the trust property, the discretion of the trustees in regard to management, and the interests of other persons in the trust. Thus we can have, on the one extreme, a trust of land for $X$, the sole beneficiary, with $X$ having the power to remove trustees, destroy the trust, or give directions to the trustee. With that situation we may compare a trust of $\$ 100,000$ to be held by trustees and invested in their discretion in trust for $A$ for life

a [Macaura v. Nthn. Assce. Co. (H.L.(N.I.)] (1925] A.C. 619.-Ed.]

- Baker v. Archer-Shee (H.L. (E) [1927] A.C 844: Cf. Hanbury, A Periodical Menace to Equitable Principles, (1928) 44 L.Q.R. 568; Mattland, Equity, Lecture IX (1909).-Ed.] 
and on his death to B for life with remainder to $C$, the trustees having full powers of management. Unless the taxpayer is willing to part with a large measure of effective ownership or control of the property, the trust device for altering situs is not satisfactory.

\section{Freezing Asset Values}

Where the estate is sufficiently large that the taxpayer has all the wealth and property he wants and requires, it becomes feasible to fix the value of the deceased's estate in such a way that it will go no higher. This process is referred to in the jargon of tax lawyers as "freezing the estate". The procedure is in its essence relatively simple. The estate property is sold to a corporation for its present market value. The corporation is owned by the deceased and his legatees. At least two classes of shares are created. The usual plan requires that the deceased own preference shares of a par value equal to the sale price. These shares are non-participating, meaning that they rank on liquidation for repayment of par value only. They also carry full voting rights, assuming that the taxpayer wishes to retain control of his formerly owned property. The intended beneficiaries of any later increase in the value of the property sold will own common, participating shares which initially are valueless, or nearly so, but increase in value as the property value increases. These common shares may be voting shares and will have to be outnumbered by the preferred shares to give the taxpayer continued control. On the other hand, these shares can if desired be another class of participating shares with no voting power.

An alternative frequently employed is to issue promissory notes to the vendor in place of non-participating shares. This practice would appear to be satisfactory, save that it is usually preferable to issue interest-bearing notes, for the idea of an interest-free debtor and creditor relationship is one that is likely to strike the average income tax assessor as artificial and invites some form of challenge.

From the standpoint of income tax, the preferred shares or notes represent a capital realization and they can be redeemed and their face value paid to the taxpaper as his needs arise without payment of individual income tax, even when they are redeemed out of proceeds of the business earned subsequent to the freezing. In order to obtain this result the shares redeemed must not be common shares within the meaning of s. $139(1)(g)$ of the Income Tax Act, ${ }^{5}$ which means that they must be precluded from participation beyond the amount paid up thereon, plus a fixed premium and dividend, on reduction or redemption of capital stock.

Where a business is sold to a corporation in a freezing operation some attention should be paid to the danger of recapture of depreciation, which ordinarily requires that the excess of the proceeds of disposition of depreciable assets over their undepreciated capital costs shall be included in computing the taxpayer's income. ${ }^{\circ}$ A sale of assets in a freezing operation such as here portrayed would not be arm's length and the capital cost of the property to the corporation would be limited to the amount of its capital cost to the taxpayer even though the actual

- R.S.C. 1952, c. 148 (am. 1952 - 53 c. $40,1953-54$ c. 57,1955 cc. 54 and 55, 1856 c. 39 , 1957 c. $29,1957-58$ c. 27,1958 c. 32,1959 c. 45,1960 c. $43,1960-61$ ce. 17 and 49 , and $1962-63$ c. 8).

- Income Tax Act, 3. 20. 
sale price was higher. Where the actual sale price of the property is less than the original capital cost to the taxpayer, the excess is deemed to have been allowed as depreciation in earlier years of the taxpayer. The end result is that the taxpayer is allowed to depreciate whatever might be the remaining undepreciated capital cost at the time of transfer. Where it is more, recapture may become a consequence. Such is the situation where assets are sold for their market value which exceeds undepreciated capital cost. But if they are sold for undepreciated capital cost, does gift tax become assessable on the deficiency below fair market value? Bear in mind that the sale is of an entire business and no gift can be established unless it is shown that the over-all price is deficient. Even here some doubt arises, both in regard to "gift" and "disposition" of property, where the purchaser company is owned by the vendor at the time of the sale. Finally, there is some authority for saying that there can be no taxable gift without a transfer with donative intent.?

Ordinarily, income assets, meaning assets which if sold, would have produced income to the taxpayer, must not be sold other than at arm's length, for less than fair market value while the vendor is carrying on business. Otherwise their fair market value will be brought into the taxpayer's income. ${ }^{8}$ Again, gift tax, and also estate tax in the event of death within three years, may be a further consequence. The gift tax threat can at least be avoided by selling at fair market value. Where a business is being disposed of, which is the normal situation here envisaged, inventory is treated as being sold in carrying on business and the profit on its sale is liable to income tax. ${ }^{\circ}$ In the case of farmers and professional businesses having no inventory, this rule extends to property that would have been included in inventory if they had been on an accrual basis. ${ }^{10}$ This income may, on election, be spread over the last three taxation years." The price attributable to inventory may be determined by agreement between vendor and purchaser but, failing agreement, the Minister may allocate a part of the sale price to inventory. In a control sale, as here envisaged, this power to determine the price paid for inventory should be exercised to best advantage, bearing in mind the income tax situation of both vendor and purchaser and their place of residence or other liability for income tax.

Where accounts receivable are included in the out and out sale of a business, or of the property of a business, the vendor and purchaser may again allocate the portion of the consideration that relates to the accounts receivable, in which event the vendor may deduct his loss on the sale of the accounts receivable, which loss is included in the purchaser's income. The purchaser assumes the right to make later deductions for doubtful debts and later bad debts. Any recovery by the purchaser of debts written off as bad by the vendor must be included in the purchaser's income. In brief, the purchaser is placed in the vendor's shoes at the contract price and the most favourable allocation of income from this source, as between vendor and purchaser, should be arranged. ${ }^{12}$

7 [Cf. Letts v. I.R.C. (Ch.D.) [1956] 3 All E.R. 588-Ed.]

8 Income Tax Act, s. $17(2)$.

D. 3. 85E.

10 8. 855 (3).

11 g. $85 E(4)$

12 s. $85 \mathrm{~F}$. 
Where the cash system of accounting is used for a business that is sold, the amount received for the debts owing to the taxpayer must be brought into the taxpayer's income for the year of sale as being receipts from carrying on business, ${ }^{13}$ and an election to tax on a three year spread of income basis is again available. ${ }^{14}$

Consideration might be given to the tax consequences of the alternative of selling a business minus the accounts receivable or minus inventory, where this course is otherwise in accord with the taxpayer's wishes.

Where the assets frozen consist of the taxpayer's controlling shares of a resident corporation, so that the business corporation is now controlled by another resident corporation, it must be borne in mind that the surplus of the business corporation is designated as of that time, meaning that it cannot be distributed tax-free to the resident holding corporation. Subsequent surplus earnings by the business corporation can be distributed to the holding company tax-free and used by it in redeeming preference shares. Dividends are regarded as derived first from these subsequent earnings. When they are exceeded the dividend is regarded as paid from designated surplus; and thereafter, from any tax-paid designated surplus, (meaning surplus that the controlled corporation might have distributed to the taxpayer tax-free, other than by way of direct dividend).

\section{DISPOSING OF THE ESTATE}

The alternative treatment of estate assets is to dispose of them prior to death in order to avoid their passing on death and being therefore taxable with estate tax. Various methods may be employed for this purpose and the tax consequences of each of them must be considered.

\section{GIFTS}

The simplest and most popular method of eliminating an estate prior to death is by means of gifts. Giving poses certain practical advantages to some taxpayers in that it affords them an opportunity to witness the result of their bounty during their lives. The choice between keeping an estate and disposing of it is, however, a matter for individual choice by each taxpayer. The tax consequences of giving must be examined from the standpoint of gift tax, estate tax and income tax.

\section{Gift Tax}

The rate of taxation under the gift tax provisions of the Income Tax Act $^{15}$ is substantially less than the rate of taxation under the Estate Tax Act and is considerably less progressive. The gift tax rate begins at $10 \%$ and rises to $28 \%$ where the aggregate taxable value of the gift exceeds $\$ 1,000,000 .^{10}$ Estate tax rates on the other hand commence at $10 \%$ at $\$ 50,000$ aggregate value and rise to the level of $44 \%$ on aggregate taxable value lying between $\$ 950,000$ and $\$ 1,100,000 .{ }^{17}$ However, the rates are difficult to compare since the gift tax rate is imposed on the total

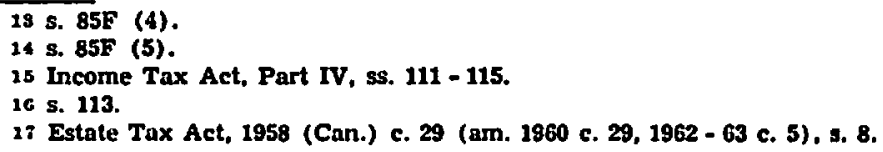


gift, whereas the stated estate tax rates represent the marginal rates of imposition on the various increments in aggregate taxable value of the estate. Satisfactory comparison can only be made through actual computation of the taxes in each instance. Thus, for a $\$ 1,000,000$ estate the effective estate tax is $\$ 309,500$ plus $\$ 20,000$, representing a total tax of $\$ 331,500$ or, roughly $331 / 2 \%$.

Also, it should be pointed out that the tax rate comparison between the giving and retention of wealth is a comparison between the lowest rate of gift tax and the highest rate of estate tax, since the gift comes off the top of the estate but incurs gift tax at the bottom of the gift tax level.

Finally, in making this comparison, it should be borne in mind that the estate is diminished by the amount of the gift plus the amount of the gift tax. In other words, there is no tax on tax where an estate is disposed of in part by way of gift. Neither is there estate tax on the gift tax where the gift is swept into the estate valuation.

In considering the gift tax, it should first be observed that it is an annual tax on the aggregate taxable value of all gifts made by a donor during the taxation year which, in the case of an individual, is the calendar year. The tax applies both to individuals and to personal corporations. Non-personal corporations are not subject to gift tax. But it must be cautioned that under section 8 of the Income Tax Act, a distribution of property to shareholders by corporations, both personal and non-personal, will result in the inclusion of the amount given in the shareholder's income. Moreover, it will not be included as a dividend and will be denied dividend tax credit of $20 \%$. Also, where corporations, both personal and non-personal, are caused by shareholders to make transfers to persons who are not shareholders the Department will, in addition to s. 8, invoke s. 16 (1) of the Income Tax Act, which provides that

A payment or transfer of property made pursuant to the direction of, or with the concurrence of, a taxpayer to some other person for the benefit of the taxpayer or as a benefit that the taxpayer desired to have conferred on the other person shall be included in computing the taxpayer's income to the extent that it would be if payment or transfer had been made to him.

Also, an appropriation of income assets to a shareholder or for his benefit for no consideration or part consideration will be treated as a sale at fair market value in computing the company's income. ${ }^{18}$

Finally, it should be noted that for estate tax purposes, a disposition by a corporation controlled by the deceased, benefitting someone related to him by blood, marriage, or adoption, is considered a disposition by the deceased for that person's benefit. ${ }^{18 a}$

Gift tax is imposed on the aggregate taxable value of all gifts made by a donor during a taxation year, and is accordingly an annual tax. "Gift" is very loosely defined for this tax. There may very well be situations in which property may be disposed of without incurring gift tax, but they are not our immediate concern in estate planning. The Income Tax Act ${ }^{10}$ simply says that gifts include a transfer, assignment or other disposition of property, wherever that property. may be situated,

28 Income Tax Act, ss. $17(5), 20(4)$.

18a Estate Tax Act, s. 3(B) (b).

10 s. $111(2)$. 
provided that such transfer, assignment or disposition is made "by way of gift".

Certain gifts are exempt from gift tax. ${ }^{20}$ First, and foremost in general importance, are all gifts that do not exceed $\$ 1,000$ annually to any person. Accordingly, a taxpayer may dispose of his entire estate in one year without payment of gift tax provided that he gives it to enough people. If any individual receives more than $\$ 1,000$ in any taxation year, such gift (or gifts) is not exempt.

Also exempt from tax is a gift to a spouse or child of the donor of an interest in real property, either alone, jointly, or in common with the donor, provided that in the case of a gift to the spouse the property is to be used as a place of residence for the spouse and the donor and, in the case of a gift to the child, that the property be used in farming operations carried on by the child or by the child and the donor. ${ }^{21}$ This exemption may not exceed $\$ 10,000$. Accordingly, where a husband and wife own farm land, gifts of $\$ 20,000$ to a child may thus be exempt. This exemption may be used only once in the donor's lifetime, and such use does not mean that the full $\$ 10,000$ exemption must have been claimed earlier. Any earlier use of this exemption, no matter how small, will exhaust it. Moreover, this exemption does not depend on the donor's election to use it, except where the donor's gift is not over $\$ 4,000$. Secondly, the subject matter of the gift must be an interest in real property: a gift of money to a child to buy a farm is not exempt under this section and care must be taken to ensure that the farm is first bought by the donor and then transferred to the child. The same caution is necessary in the case of a gift of a matrimonial home to a spouse.

The legislation requires that the gift of these properties be used as a matrimonial residence and in farming operations carried on by the child. No requirement is stated as to the term of such use. Presumably this use requirement is simply in modification of the purpose of the gift and a later change in use would not appear to disqualify the gift for exemption, though it might render proof of the purpose of the gift more difficult if it is not sufficiently evidenced. Where the gift of farm land is to a daughter married to a farmer, any question of whether she carries on farming operations may be avoided by placing her in formal partnership with her husband. Since she owns part of the farm land, the Minister may even be persuaded to allow an allocation of income in recognition of her property and effort, thus adding the advantage of an income split. ${ }^{22}$

Also excluded from the gift tax are donationes mortis causa (they being taxed with Estate Tax), and a gift to take effect upon the death of the donor or so given that the donee would not obtain the benefit of the gift until the donor's death. ${ }^{23}$ The meaning of this exemption is by no means clear. A gift of a remainder after the donor's life estate may well constitute a present benefit to the donee even though his possession is postponed. Finally, gifts to charitable organizations, corporations and trusts resident in Canada and to the Government of Canada, a municipality or province, are exempt.24

20 8. $112(4)$

21 s. $112(4)$ (ba).

22 s. $21(4)$

29 5s. $112(4)$ (a).(b).

21 8s. $112(d)(c)$.(d). 
Apart from exemptions, a deduction is allowed in computing the aggregate taxable value of gifts made during each taxation year. This deduction is the greater of $\$ 4,000$ or one-half the difference between the taxable income of the donor for the immediately preceding taxation year and his income tax payable thereon for that year under Part I of the Income Tax Act.". Thus, any taxpayer can make non-exempt gifts totalling $\$ 4,000$ without payment of tax; and taxpayers with income high enough (usually in the vicinity of $\$ 10,000$ per year) can make gifts in excess of that amount. A married taxpayer with no children and income of $\$ 20,000$ a year has a deduction for gift tax of approximately $\$ 6,300$. Gift tax accordingly represents one of the few taxes with a regressive rate aspect, minor though it may be.

\section{Estate Tax}

From the standpoint of estate tax, certain precautions must be exercised under any program of giving.

First, it should be noted that the making of gifts will not diminish the estate for estate tax purposes unless the donor has survived the date of gift by more than three years. This provision is intended to prevent gifts from being made in anticipation of death so as to avoid estate taxes. Where the donor dies, the amount of gift tax paid on gifts that have been swept into the value of the estate is allowed as a credit against estate taxes. ${ }^{20}$ This provision takes the risk out of planning a gift programme to reduce estate taxes. Where estate tax payable on gifts made within three years of death is less than the amount of gift tax that has been paid on such gifts, the excess is deemed to be an overpayment made by the deceased in respect of estate tax and is refundable to the estate together with interest. ${ }^{27}$

It should be noted that where gifts within three years of death are swept into the value of the estate they will then be valued as of the date of death. This requirement points to the wisdom of making gifts of cash instead of property, wherever possible, so as to fix the value of the gift and prevent a rise in value of the property from affecting the estate. The donee can then purchase the property from the donor with his cash gift. The purchase back can even be postponed until January 1st of the next year to invoke another $\$ 4,000$ deduction. Also, even if the cash consideration on purchase back should be inadequate, the value of the gift (the inadequacy) will be fixed for Estate Tax purposes. ${ }^{28}$

It should be noted that the definition of gift within three years of death is much broader in the Estate Tax Act than in the gift tax provisions of the Income Tax Act. Under the Estate Tax Act gifts include, (1) the artificial creation by the deceased or with his consent of a debt or right enforceable against him or his property or property of which he was or might be competent to dispose, (2) the extinguishment by him or with his consent of debts or rights enforceable by him, and (3) the operation of any statute or law limiting the bringing of actions to render a debt or right unenforceable against the deceased. ${ }^{20}$

25 a. $112(2)$.

26 Estate Tax Act, 8. 9(2).

27 Income Tax Act, 8. 115 (1).

28 Estate Tax Act, 8. $3(1)(0)$.

20 Estate Tax Act, 8. 3(3). 
Second, gifts made at any time will be swept into the deceased's estate unless actual and bona fide possession and enjoyment of the property given were assumed by the donee or by his trustee or agent and therefore retained to the entire exclusion of the deceased and to the entire exclusion of any benefit to the deceased, whether by contract or otherwise, for a period of at least three years prior to the deceased's death. ${ }^{30}$ Again, in seeking to avoid the possible application of this section, it is desirable to make gifts in the form of cash wherever possible, thereby destroying the relationship between later benefits of possession and enjoyment conferred by a donee on a donor and any gifts of property from which those later benefits may be traced. The tracing of benefits of proprietary possession and enjoyment to an earlier exchange of cash poses a difficult problem.

\section{Income Tax}

We come now to consideration of the income tax implications of giving. There are three considerations that should be noted.

1. A gift of property to a spouse, or to someone who later becomes the donor's spouse, does not produce a split in income as between donor and donee. ${ }^{32}$ The same denial of income splitting applies to transfers of property since 1930 to a person who was under 19 year of age ${ }^{32}$ and continues for the lifetime of the taxpayer, or while he is resident in Canada, or until the transferee attains the age of 19 years.

2. Where a gift is made by an employer to an employee, future employee or past employee, there is considerable danger of this gift being income of the employee unless a court can be persuaded that it cannot reasonably be regarded as having been received as consideration for accepting the offer, or for entering into the employment, or as remuneration for services rendered as an officer, or under the contract for employment, or as consideration or part consideration for the officer or employee agreeing that he will or will not do something before or after termination of the employment. ${ }^{33}$ Giving with pure donative intent would appear to be unaffected by this legislation, provided that such intent can be proved.

3. Where a taxpayer dies leaving income assets, such as stock in trade or agricultural produce or other assets that, if sold, would produce income for him, this property is considered to have been realized by the deceased, and his estate will be subjected to income tax on the profit represented by the value of these assets. ${ }^{34}$ This income may be spread over five years, but the more important tax relief from this statutory realization is the exclusion from income where these assets are distributed to beneficiaries before the income tax for the year of death has been assessed. However, the beneficiaries must bring the proceeds of these assets into income upon their realization of them. ${ }^{3 s}$

\footnotetext{
3o Estate Tax Act, a. $3(1)(d)$.

31 Income Tax Act, 8. 21(1):

(1) Where a person has, on or after Aubust 1, 1917, transferred property, elther directly or indirectly, by means of a trust or by any other means whatsoever, to his spouse, or to a person who has since become his spouse, the income for a taxation year from the property or from property substituted therefor shall, during the lifetime of the transferor while he is resident in Canada and the transferee is his spouse, be deemed to be income of the transferor and not of the transferee. 32 s. $22(1)$

38 8. 25.

34 8. $64(2)$.

85 8. $64(3)$.
} 
It has never been determined that an inter vivos gift of income assets effects their realization for purposes of income tax. Thus, if a farmer gives livestock or grain to his son it is by no means clear that the farmer must be treated as having realized the market value of that grain. It is probable that the deducted cost of producing that produce must be added back to the years of assessment in which it has been deducted. An obvious problem of tracing develops in this connection. Also, the fouryear limitation rule on reassessment in the absence of fraud or misrepresentation may operate to protect the taxpayer. ${ }^{38}$

\section{Mode of Giving}

Finally, some mention should be made of the proper manner of giving. All giving should be documented or evidenced in some way so as to render possible proof of the gift and of the circumstances of the giving. This proof should extend to establishing the amount of the gift through valuation where property is transferred.

Various alternatives may be employed. Exempt gifts and deductible gifts may be declared on the income tax form, which simply asks whether gifts of more than $\$ 1,000$ have been made to any person during the taxation year and to whom. Mention of gifts in excess of this amount provides the Department with some degree of notice, but much fuller notice of gifts is afforded by filing a gift tax return showing full details of all gifts that have been made. However, it is suggested that the taxpayer wishing to be cautious should proceed further and make gifts to an extent that justifies even a small gift tax assessment, rather than stopping short at the maximum deduction. The cost need only be small but the advantage is that the matter is brought forcefully to the attention of the Department to the extent of requiring an assessment. Thereafter review and reassessment is limited to four years. ${ }^{37}$ Otherwise the Department can re-open the whole matter, including the past value of property given, after a length of time that renders proof impossible, demanding $6 \%$ interest as well as tax on any disputed amount.

\section{LOSS TRANSACTIONS}

Closely associated with giving is the alternative of selling property for less than its value. Reviewed from the point of view of gift tax, it is not clear that such sales are gifts within the meaning of section 111 of the Income Tax Act. Yet for our purposes we must assume any deficiency of consideration to be subject to gift tax because an assessment would likely be made, notwithstanding that the definition of gift offers little guidance as to how far it proceeds beyond the technical, conveyancer's meaning of that term. Let us assume then that the gift tax consequences earlier referred to are applicable. The amount of gift is probably fixed as the deficiency in the money or property consideration flowing to the vendor, rather than the deficiency of consideration flowing from the purchaser. A sale by $A$ to $B$ for full or partial consideration paid to $C$ might be construed as a gift from $A$ to $C$ or to both $B$ and $C$.

The Estate Tax Act seems to deal directly with this type of transfer in referring to a disposition of property for partial consideration, sweeping into the value of the estate all property disposed of under any dis-

30 s. $46(4)$.

37 ibid. 
position made within three years prior to death for partial consideration to the extent that the value of the property as of the date of disposition exceeds the consideration paid to the deceased. ${ }^{38}$ Hence, the value of the disposition is fixed and a subsequent rise or fall in the value of the property does not affect the size of the estate.

And as noted above, the Act also includes in the value of the estate all property disposed of without actual and bona fide possession and enjoyment being assumed and retained by the disponee for at least three years prior to the disponer's death. ${ }^{30}$

However, notwithstanding anything contained in section 3 (which adds to the aggregate net value of the property passing) there is not to be included in the taxable estate property acquired pursuant to a bona fide purchase from the deceased for full consideration in money or money's worth paid or agreed to be paid to the deceased for his own use or benefit; and if the purchase was not for full consideration there is included in computing aggregate net value only the-deficiency of the consideration as of the date of purchase. ${ }^{10}$ Hence, where possession and enjoyment of property are to be retained by the deceased until his death, a sale of that property for deficient consideration appears to afford the advantage not only of fixing the value of the gift, but of excluding it from the operation of s. 3 (1) (d), which would add its full value to the value of the estate.

From the standpoint of income tax, the sale (other than at arm's length) of property below its fair market value by anyone carrying on business in Canada results in the vendor being treated as having received the full market value, 11 and a sale by a corporation or an appropriation of its property to shareholders for consideration less than fair market value is treated as a sale for full fair market value in computing the corporation's income. ${ }^{12}$

Sale of a business at market value is employed both as a means of fixing the value of an estate where the taxpayer is contemplating retirement, and also so that the successor to the business can receive the advice and service of the taxpayer. Such sales have neither gift tax nor estate tax consequences in attracting tax, unless an annunity for life or for a period determinable by reference to death is provided by way of consideration, which will be regarded as consideration only to the extent that it exceeds in value the capital value of an annunity of 5 per cent of the value of the property sold, ${ }^{43}$ and only to the extent that this excess has been paid to the deceased before death. Thus an annuity worth the full market value of the property sold plus 5 per cent thereon does not fully diminish the estate if the annuitant predeceases his actuarial life expectancy. Sale in consideration for an annuity payable to the taxpayer's wife raises interesting possibilities, provided such an arrangement is satisfactory.

The same points of caution should be observed in sales at or below fair market value as were noted above for sales in order to freeze the estate.

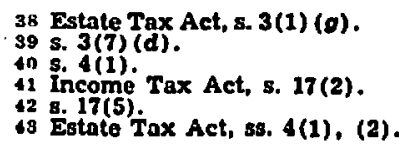


One income tax concession should be mentioned. Where a farm or farming property, or a fishing vessel, is sold by a farmer or fisherman to his child, such child is not required to compute capital cost allowance on the undepreciated capital cost of his father, but may compute on the basis of the cost to him of that property, provided that it does not exceed fair market value." Also, a farm may be sold for capital payable by way of a share of crops or other amount dependent on production or use of the property without such payments being fully regarded as income. ${ }^{45}$

\section{GIFTS BY SETTLEMENT}

Settlements, meaning inter vivos transfers in trust to be held in successive interest, are in general of no effect in diminishing the estate of the settlor where they are revocable. ${ }^{\text {to }}$

An irrevocable settlement will also be ineffectual in reducing the estate of the settlor where an interest in such property for life or for any other period determinable by reference to death (of the settlor) is reserved either expressly or by implication to the deceased as settlor. ${ }^{47}$ Again, reservation of a life interest to a taxpayer's wife may be satisfactory in some situations.

Considerable advantage is obtainable through the use of an irrevocable trust established during lifetime. Beneficiaries, particularly if they are lacking in competence, are relieved from the responsibility of managing their investment and both good and continuous management can be assured. Also, there may exist an advantage of being able to divide the property among beneficiaries with maximum flexibility, including the exercise of discretion by trusted persons after the taxpayer is dead. Income tax may be reduced by dividing income among various persons as beneficiaries. In this connection it should again be noted that no division of income is obtained if the wife or persons under 19 years of age were beneficiaries. There is also no division of income where under the trust the possibility exists of the property becoming again the property of the settlor or where he has received the right to dispose of the property or direct its disposition. ${ }^{48}$ Otherwise the trust is taxed as an individual and may deduct from its income the trust income distributable among the beneficiaries who are then regarded as the recipients of it; if various trusts are set up in such a way as to provide income to the same beneficiaries they will be joined together and taxed as one individual, so that no further income splitting is obtainable by multiplying the number of trusts. Considerable saving in probate and administration expenses is obtainable through the use of the trust and moreover, a trust is more private, for (unlike a will) the trust does not become a matter of public record and does not form part of the deceased's estate. As already indicated, a trust may be used to localize assets, and by setting up successive interests under a trust (bearing in mind the ordinary limitations, such as the rule against perpetuities), estate tax may be avoided on the later transfers of possession from life tenants to

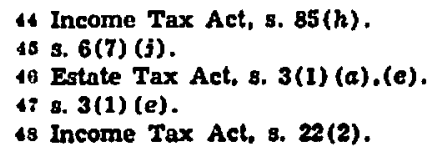


life tenants, etc., to remaindermen. English decisions ${ }^{40}$ suggest the contrary, but appear inapplicable because of differences between the Canadian Estate Tax Act and the English Finance Act. ${ }^{\text {so }}$

The trust device has some merit for the management of a business. Continuity of control and management, transferability, and reasonable perpetuity of existence can all be achieved just as with a corporation. No limited liability is obtainable: in many businesses this feature is not important and in others it can be reasonably well subsituted by insurance. In Alberta there is a statutory limitation on setting up an unincorporated business corporation of more than 20 shareholders. ${ }^{51}$

Dispositions of property by way of trust will be treated as ordinary gifts for gift tax purposes; and if they are caught by any of the gift provisions of section 3 they will be swept into the valuation of the estate for estate tax purposes.

The following may be noted as the main income tax consequences of setting up trusts: (1) The trustee is required to pay tax on the trust income as an individual at the graduated rate applicable to individuals. (2) The income distributed to the trust beneficiaries is deductible from the trust income and will be treated as income of the beneficiary. (3) Capital cost allowance on depreciable assets may be deducted in computing the trust income. The trustees are allowed the alternative of determining that some of the deductible capital cost allowance may be deducted by the beneficiaries. This allocation is a matter that can also be dealt with in the trust instrument so as to prevent dispute between the trustee and beneficiaries. Beneficiaries who have claimed capital cost allowance will, of course, be required to undergo recapture of depreciation on ultimate disposal of the depreciable assets. (4) Depletion allowance is similarly claimable by a trust and where income is allocated among beneficiaries the depletion allowance is similarly divisible.

(5) Where the trust receives dividends which are in turn passed to beneficiaries, they are allowed the dividend tax credit, if otherwise justified, and the dividend is not treated as income derived from a new source. (6) Income paid to the settlor will, of course, be treated as his income. (7) Moreover, if the trust is so created that the trust property may revert to the settlor or may pass to persons determined by him at a later date or shall not be disposed of except with the consent or in accordance with the direction of the settlor during his lifetime, the income from the trust property will be treated as his income. (8) Also the value of benefits to a taxpayer under a trust must be included in computing his income for the year ${ }^{52}$ and these include any part of an amount paid by the trust out of the income for the upkeep, maintenance or taxes on property required to be maintained for the use of a tenant for life. (9) Trusts created by deed must adopt the calendar year as the taxation year: testamentary trusts may select a fiscal period ending in a calendar year.

49 [e.g. Earl Cowley v. I.R.C. (H.L.(E)) [1899] A.C. 198-Ed.]

50 [In any event, it is not the practice of the M.N.R. to assess a life interest for double death dutles. See the notes in De Boo's Estate Tax manual p. 1-346; C.C.H. Canadian Estate Tax and Gift Tax Reporter, 4144-45.-Ed.]

51 Companles Act. R.S.A. 1955 c. 53 s. 8.

s2 Income Tax Act, 8. 65 . 


\section{TRANSFERS IN CONSIDERATION OF MARRIAGE}

Transfers in consideration of marriage are neither stated to be gifts, nor are they classed as sales for no consideration. Rather, transfers and settlements in consideration of marriage are specially swept into the estate if made within three years of death. ${ }^{53}$ Also, property agreed to be transferred or settled in consideration of marriage is swept into the estate to the extent that it was actually transferred or settled within three years prior to death. ${ }^{\text {st }}$ Property that is the subject matter of a transfer, settlement or agreement made at any time in consideration of marriage is swept into the estate where any interest in such property for life or any other period determinable by reference to death is reserved either expressly or by implication to the deceased. ${ }^{55}$ Debts and encumbrances created in consideration of marriage are not deductible in computing the aggregate net value of an estate. ${ }^{8 g}$

In connection with the relationship between husband and wife, it should be noted that there must be included in the valuation of an estate, for estate tax purposes, any estate in dower or by the curtesy in any property of the deceased to which the spouse becomes entitled on death. Property disposed of to a spouse within three years of death in consideration of a release of right of dower or curtesy is also included;"37 and debts arising and encumbrances created through a disposition of property to a spouse within three years of death in consideration for a release of these rights are not deductible. ${ }^{68}$

\section{JOINT INTERESTS}

Where real property is placed in joint tenancy with the taxpayer it is treated as a gift for gift tax purposes, the amount of the gift being onehalf the value of the property. This conclusion has been reached by the Tax Appeal Board and for our purposes must be taken as final. This means that the usual gift tax is assessable on the transferor in respect of the transferee's interest. The once-in-a-lifetime gift of real property, it may be noted, extends to dispositions "either alone, or jointly or in common with the donor" and this language is probably intended to permit the donor and donee to hold as joint tenants after the gift.

From the standpoint of estate tax, different considerations apply. Property held jointly by the deceased is swept into the estate "to the extent of the beneficial interest therein arising or accruing by survivorship or otherwise on the death of the deceased".so Notwithstanding the inappropriate nature of the language, we must assume that the value of the deceased's interest in the property jointly held will be included in his estate as of the date of his death. Gift tax may not be deductible where the donor survives because the gift tax was not imposed on the deceased donee. It is further to be noted that this inclusion of joint interests does not depend on the deceased's having made a contribution to the acquisition of these joint interests, and herein lies the serious danger of jointly held property. The transfer by a husband to his wife

53 Estate Tax Act, s. 3(1) (n).

54 8. $3(1)(0)$.

65 s. $3(1)(p)$

50 3. 6(b).

57 \&. $3(1)(g)$.

og Estate Tax Act, a. $3(1)(f)$. 
of land in joint tenancy results in gift tax on one-half the value as of the date of the transfer. Death of the husband results in further estate taxation on the value as of the date of death of the one-half interest still held by the husband at that time. No credit is allowed for the gift tax. But, should the wife die first the value of her half interest is swept into her estate notwithstanding that it is returned to the husband who paid the full consideration for it. Moreover, gift tax may not be creditable because the gift tax was paid by the husband whereas the estate tax now payable is the obligation of the wife's estate. Finally, the husband emerges with the original problem of getting the property once more out of his estate.

From the standpoint of income tax, the full income from the property placed in joint tenancy will be treated as the income of the transferor spouse. ${ }^{30}$ Whether transfers for full consideration are included in this statutory directive has not yet been determined.

Different problems arise in connection with joint bank accounts and joint annuities. In the case where funds are placed in a joint bank account, it is by no means clear that there has been a completed disposition for gift tax purpose while the funds remain undrawn by the joint owner. Yet when they are drawn by the donee as joint owner the disposition is not completed by the alleged donor. The situation bears some resemblance to the creation of a power of appropriation in the joint owner. Similarly, in the event of death of the contributor to the account, the deceased's power of withdrawal is simply extinguished, and the language of s. $3(1)(f)$ is most inappropriate for taxation of the survivor; not to mention the problem of valuing any benefit that may arise, because s. 3(4a) does not extend to s. $3(1)(f)$. Similar problems arise in connection with joint annuities in $s .3(1)(j)$, though they are in part cured by s. 3 (4a). A transfer to joint ownership may be a disposition operating as an immediate gift for purposes of the Estate Tax Act, in view of the broad definition in s. $3(3)$.

Existing joint tenancies may be destroyed by a conveyance by the joint tenants to themselves as tenants in common. Where joint tenancy is desired for the benefit of survivorship that it affords it may still be used, provided that sufficient trusts are engrafted on the legal estate held in joint tenancy and they are so designed as to ensure that the deceased is parting with his ownership only if any when he is survived by his co-tenant.

\section{INSURANCE}

Life insurance is probably the most generally useful device in estate planning. Its main function is to provide an estate where the earning ability of the taxpayer would not enable him to provide one otherwise, except late in his life when, in point of fact, his need for an estate may be considerably reduced. Insurance companies and their agents are extremely useful and willing to be of service in helping select the type of insurance that best meets the client's needs. On viewing insurance from the standpoint of estate taxation considerable advantages are apparent. The proceeds of insurance are not swept into the valuation of the estate unless the deceased is directly the owner of the policy, or

60 Income Tax Act 8. $21(1)$. 
controls it in any of the manners set forth in s. $3(1)(m)$ of the Estate Tax Act.

(1) Proceeds are taxable, if the deceased owns the policy either outright or jointly or in common with anyone else.

(2) Again, policy proceeds are taxed if the policy is owned alone, jointly or in common with another by a trustee and the terms of the trust are subject to alteration by the deceased.

(3) Insurance proceeds are also taxed if the policy is owned alone, jointly or in common with another by a corporation controlled by the deceased and any part of the policy proceeds are payable to or for the benefit of the estate of the deceased or his spouse or child.

Ownership of a policy of insurance by anyone includes a reference to insurance in which such person had an estate or interest or in relation to which he had power enabling him either alone or with others to (i) change the beneficiary, (ii) charge or pledge the policy as security for any purpose, (iii) borrow from the insurer on the security of the policy, (iv) cancel, surrender or otherwise terminate the policy, or (v) assign the policy or revoke any assignment thereof. ${ }^{02}$

(4) Also, it should be noted that there is some danger of life insurance proceeds being swept into the valuation of the estate as being an interest purchased or provided by the deceased, either alone or in concert or by arrangement with another person, to the extent of the beneficial interest therein arising or accruing by survivorship or otherwise on the death of the deceased, ${ }^{, 2}$ though there has been some open expression by members of the Taxation Division that this would not be so.

(5) Finally, insurance on the deceased's life owned by a corporation, either alone, jointly or in common with anyone other than the deceased or a trust that is alterable by the deceased and payable to the corporation will be taxed to the extent that it exceeds the corporation's business income (other than of a financial nature) computed over a period of the five years prior to the deceased's death."s

It would appear that the deceased is free to pay the policy premiums, provided he is not the owner of the policy and if the owner of the policy is named as beneficiary. An obvious situation is that where the wife owns an insurance policy on her husband's life payable to herself. Where she, as owner, is not named as the beneficiary and the deceased pays the premious, it has been suggested that liability for estate taxes may arise, though the matter has never been clearly settled. Where a wife has independent income with which to pay the premiums no problem would appear to arise so far as policy proceeds being swept into the estate of the insured's life is concerned.

From the standpoint of gift tax any premiums paid by the deceased will naturally be considered as gifts. From the standpoint of income tax life insurance proceeds are not taxable as income when they are paid on death. The premiums are, of course, not deductible.

Vesting the ownership of insurance in the beneficiary is satisfactory only when there is no danger of loss of insurability and disagreement

62 Estate Tax Act, 8. 3(5).

62 в. $3(1)(3)$.

62 89. $3(1)(m)(b), 3(5)(b)$. 
between the taxpayer and the owner of the insurance. Estranged wives are not satisfactory owners of a husband's life insurance. Such situations can be provided for (if s. 3(1) (j) can be safely ignored) by an insurance trust in which the trustees own the insurance and pay the premiums from income derived from trust property in turn derived from the deceased and the ownership of the policy is made to shift upon the event of separation.

A method is available whereby persons who are uninsurable may take advantage of the exclusion of life insurance from the valuation of their estates. A number of insurance companies offer a combined insurance and annuity plan whereby if a person purchases a single premium life annuity with no term certain, they will issue life insurance on the life of such person at the same time for an amount approximately equal to the purchase price of the annuity. On death the annuity is lost, but the insurance proceeds are received outside the estate assets.

\section{PROTECTION OF BUSINESS INTERESTS}

Earlier, we noted one of Wormser's basic principles that the provision of opportunity is far more important in estate planning than the provision of property. This observation is essentially a sound one and for this reason attention should constantly be paid to the non-proprietory benefits that may flow from generation to generation. The exemption from estate taxation of reasonable giving as part of ordinary and normal expenditure $^{04}$ must be borne in mind. It enables taxpayers to educate thoroughly, train, provide travel and experience and otherwise equip their beneficiaries for life without estate tax consequences. This form of legacy is not to be underestimated in considering the disposition of an estate, particularly when planning is being pursued early in the taxpayer's lifetime.

The non-proprietory transmission of benefits without taxation can be more concrete in its form and can even extend to a business. The opportunity of professional men, for example lawyers, to transmit the full benefit of business association without payment of estate tax is obvious and the effectiveness of this practice is well indicated by the frequency by which it is carried out. But even non-professional businesses may be handed down in this indirect manner involving no proprietory exchange. Consider the situation where a hardware merchant, seeing his son established in competition with him, can over a relatively short period effect a shift of his goodwill and business volume to his son without difficulty. There is not even any requirement for payment of income tax where income is foregone by services voluntarily rendered without compensation in an effort to transmit business experience, business contact, and business relationships.

As we move into the area of businesses involving substantial capital investment the practicality of the situation changes. When the taxpayer reaches the stage of retirement the business can be sold intact to the prospective legatee and payment can be deferred until the taxpayer's death. If the taxpayer is insurable, insurance owned by the purchaser can be usefully employed as a method of financing the purchase. Assuming that the sale is for full consideration, there will be no gift tax and,

of Estate Tax Act. 8. 7(1) (e). 
moreover, the sale will freeze the estate and protect it against a rise in the value of the business. The sale not being at arm's length, no new basis for depreciation is established. At the same time there is no recapture unless the sale of depreciable assets is for a price in excess of undepreciated capital cost.

Where business is carried on in partnership, the estate planner should examine into the affairs of the partner and endeavour to appraise the consequences of his death from the point of view of preserving the business from destruction by (1) the impact of estate tax and income tax and (2) the loss to the business of his services.

The partnership will ordinarily be dissolved by the death of a partner and unless provision is made for its continuance, may have to be completely wound up at considerable loss to the taxpayer's survivors. Various alternatives may be suggested. Arrangements may be made for sale of the partnership interest before the taxpayer dies, provided that he is presently ready for retirement. On the other hand, where partners are roughly equal in their interest and where retirement is not an immediate matter of concern, provision may be made in the form of a buy and sell agreement, whereby if one partner dies the other will purchase his interest in the firm. This form of agreement may be funded by insurance or, if either party is uninsurable, money may be provided by borrowing or by simply spreading the payments over a lengthy period.

Where the buy and sell agreement is being funded by insurance, it may be advisable to set up a trust in which the trustee collects the policy money on behalf of the surviving partner and transfers it to the deceased's estate in consideration for the interest in the partnership which he transfers back. From the tax point of view the main consideration to bear in mind is that the insurance proceeds must not be taxable to the deceased's estate, for otherwise estate tax on both the insurance and the business partnership share will be swept into the estate valuation. In regard to a sale of a business interest for a share of profits prior to death of the partner who remains as an employee, the main threat of estate tax lies in the argument that the deceased partner may not be considered as having parted with possession and enjoyment of the business interest sold and transferred. Hence wherever possible, cash should be exchanged rather than property.

In the case of professional partnerships it is common to provide for retirement of a partner on a reduced share of the profits for a period of time or for his going on salary at a reduced level of activity in consideration of his surrender of his interest in the firm. This situation has the merit of excluding goodwill from any valuation of property passing on the death of an active partner. While goodwill attributable to the partner personally will ordinarily be extinguished by his death, goodwill attributable to the firm will survive and be valued on his death.

It is noteworthy that an annuity paid as consideration for the sale of any property (and this includes a share in a business) is only considered to be consideration for that property to the extent the annunity exceeds 5 per cent of the value of the property annually, and that only when it has actually been paid to the deceased prior to his death. Thus, where death occurs soon after the agreement virtually no consideration will be considered as having been paid."s

os Estate Tax Act, ss. 3(1) (h), 4(1), \&(2). 
Where under a buy and sell agreement an interest in a partnership is sold, the purchase to take place after the deceased's death, it must be borne in mind that the consideration must equal the value at the date of death of the interest sold. The estate is not thereby frozen as of the date of the agreement. ${ }^{\circ 0}$ The only amount deductible is the consideration actually paid to the deceased's estate before he died. The mutual covenant by the surviving partner to sell and transfer his share of the partnership business in the event of his earlier death is not such consideration." $^{\text {"z }}$

Where a partnership subsists between partners there may be some merit in incorporating the partnership as a step in estate planning. Incorporation adds continuity to the business organization. It may also facilitate the sale of the deceased's interest after death by representing that interest in the form of shares, which may be voting or non-voting, and the flexibility by which the scheme of transfer can be effected is considerably enhanced. Where a business is incorporated and provision is to be made for the death of a shareholder the main problem met with is the raising of money with which to pay estate tax on the value of the deceased's shares.

One solution is the use of insurance owned by the survivors on the deceased's life with which estate taxes may be discharged. Insurance owned by a corporation controlled by the deceased will be brought into the valuation of the deceased's estate if the corporation is controlled by the deceased and if any part of the proceeds is payable to the deceased's estate or any of the deceased's wife or children. Insurance owned by such corporation and payable to the corporation will be added to the value of the deceased's estate to the extent that it exceeds five year's income of the corporation. Also, if the deceased owns common (participating) shares in any company owning insurance on his life the insurance proceeds will add to the value of those shares unless such proceeds have otherwise been swept into the value of his estate. ${ }^{88}$ Hence, control of the corporation, immediately prior to death, and the ownership of growth stock in the corporation are features to watch where corporation-owned insurance is to be used as a method of providing money to redeem estate shares for payment of estate tax.

Where corporate earned surplus has been reinvested in the business the problem becomes particularly acute, since this reinvestment and the total advantage derived from it will feature in a valuation of the shares. This valuation results in estate tax and the problem arises of providing money with which to pay that tax. Where money is on hand with the corporation, its distribution involves payment both of income tax and estate tax.

It is not possible at this point to enter into a full discussion of the ways and means of extracting undistributed surplus of the corporation free of income tax as a measure in anticipation of a shareholder's death. Needless to say the extraction of surplus tax-free has been rendered more and more difficult. But it is unlikely ever to be prevented.

Apart from life insurance and the distribution of surplus other methods may be employed for funding a purchase or redemption of

6e This Is the effect of $89.3(1)(3)$ and $4(3)$ of the Estate Tax Act. a7 8. $3(4)$

68 8. 32. 
estate shares. A sinking fund may be established by shareholders to provide a fund for purchase of shares. A promissory note may be used as a method of extending credit to the surviving shareholders. Bank borrowing on the security of the shares, is another possibility, especially if the business is flourishing. Also, shares may be disposed of piecemeal under the agreement, allowing the estate to remain shareholder for a limited time. This alternative does not provide money for the payment of debts unless, in addition, a power to borrow on the security of shares is vested in the trustee of the estate.

\section{VALUATIONS}

Some mention should be made of the provisions of the Estate Tax Act in respect of valuation. The general position is that all assets are to be valued as of the date of the death of the deceased, without regard to any increase or decrease in such value after that date. Section 58 (1) (s) of the Estate Tax Act provides that any income, right, annuity, terms of years, life estate, similar estate, or interest in expectancy shall be valued according to mortality and interest tables as prescribed by regulations under the Act. Other property is simply stated to be valued at fair market value, which is a term of indefinite meaning. The general proposition expressed by Courts is that fair market value is the price agreed upon between a willing vendor and willing but not anxious purchaser selling and buying for cash in a free and open market. The question of valuation leaves considerable room for difference of opinion, and the estate is always free to hire its own valuators and to dispute the valuation placed on property by the Department.

Some special rules are also included in the Act. These are comprised in sections 26 to 33 comprising division F. It is first to be noted that no allowance or deduction is to be made on account of any income tax. The precise operation of this provision has received little judicial interpretation. We must assume that it applies to potential tax liability only. If any income tax is payable or outstanding against any properties swept into the deceased's estate, it is to be deducted. ${ }^{09}$ Gift taxes on properties swept into the estate would appear to be deductible. Listed shares of stock are to be valued according to market quotations as of the time of death. However, if the corporation is controlled by the deceased and persons connected by him through blood, marriage or adoption, then this stock market valuation does not apply, and the shares must be valued by the corporation, and in that connection valuation may proceed through book value, adjusted book value, by capitalization of the corporation's earnings, or by examining the dividend value of the shares. Certain points should be borne in mind in making this type of corporation valuation. Goodwill of the corporation may be considerably cut down by the shareholder's death and any of the ways in which the death affects the business must not be overlooked in valuing the corporation. Another factor is control. If there belonged to the deceased and his relatives by blood, marriage or adoption, enough shares to control the corporation the deceased's shares are to be valued as controlling shares and the value of that control is to be taken into account.70 
Debts outstanding against the deceased's estate and owed to relatives by blood, marriage or adoption or to a corporation controlled by the deceased and such relatives, are to be valued as due and payable unless it is established that these persons are in fact dealing at arm's length.

One area of disagreement lies where valuation must be made retroactively as of some time prior to death, for example, in determining where a deceased person disposed of property for inadequate consideration. The recommended practice in this regard is to obtain the assistance of independent valuators. In some instances, where there is not room for great difference of opinion, it may be advisable to seek agreement with the taxation authorities at the time of the transaction in the hope that they will not change their minds and re-open the question of value after the deceased has died.

Where property has been disposed of by gift and, at a subsequent time during the deceased's lifetime, that property has been disposed of in turn by the donee, the value of the property disposed of is deemed to be the value as of the time of the donee's later disposition of it. ${ }^{71}$ Any property not disposed of by the donee during his lifetime is deemed to have been disposed of by him immediately prior to his death. Where shares are disposed of during lifetime and later a stock divided is paid to the donee the value of the dividend shares is to be added to the value of the shares disposed of.

\section{ADMINISTRATION}

Many are the problems that arise in regard to planning for the administration of a deceased's estate after his death. In this area the law has been relatively stable for some time and the new requirements are mainly due to the innovations in estate administration resulting from plans to avoid taxation.

One of the first of these is the necessity that the deceased's will provide for payment of estate tax. Unless special provision is made the estate tax will be borne in the same proportion as the deceased's estate is distributed, and very often this means that the deceased's intentions are defeated since he did not contemplate the reduction of gifts due to estate tax in establishing their amount. The usual provision is that it be paid out of the residue after all specific gifts have been fully made.

Another series of problems is raised by the establishment of trusts under wills in order to minimize the effect of estate tax. The use of trusts established by will is not new and neither are the problems that ordinarily arise, one of the main ones being the selection of trustees. In large estates where complicated measures must be taken, the use of corporate trustees with elaborate facilities is usually recommended. On the other hand, in areas where personal discretion (as compared to business discretion) must be exercised, it is frequently thought advisable to select an individual trustee who is well acquainted with the deceased's family and has some knowledge and understanding of the deceased's values and attitudes as well as being possessed of good judgment. Sometimes a combination of these types of trustees is used. Not infrequently a wife or surviving spouse is made trustee, but unless she possesses business ability her presence may be an encumbrance and

71 8. 30. 
may simply provide a form of unmerited protection for the corporate trustee, who is jointly liable with the wife for mismanagement.

Considerable attention should be paid to the discretion of the trustee both as to dealing with the estate assets and choice of investment. The common law and statute law should be modified wherever the demand of fair working for the scheme proposed renders modification advisable or necessary. 